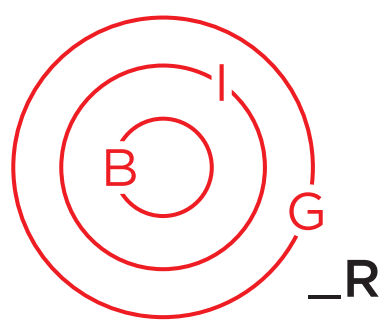

ARTICLE

\title{
The Label 'Refugee' and its Impacts on Border Policies
}

\section{Claude Beaupre ${ }^{i}$ and Franziska Fischer ${ }^{\text {ii }}$}

In this paper the authors adopt a constructivist approach to explain the efforts of reborderisation following the so-called 'Refugee Crisis' unfolding in the European Union after a sharp influx of refugees in 2015. One of the core principles of the European Union, the freedom of movement, is heavily challenged, through the perception of security threats and economic burden that is associated with the arrival of people seeking asylum in large numbers. Through a discourse analysis centring around the label 'refugee', which experienced a shift in meaning, this paper aims to display the driving social force that catalysed political actions to reintroduce borders between European Union Member States as a tool to recreate the illusion of control over the influx of people. Germany and France, as pioneers of the principle of freedom of movement in Europe, serve as empirical case studies for the efforts to reinstate control through reborderisation.

\section{Introduction}

The Refugee Crisis also known as the Migrant Crisis or the Migration Crisis-depending on inadvertent or wilful muddling of these terms-refers to a period of time in 2015 and 2016 when human migration from Asia and Africa towards Europe became a hot topic of discussion. The rise of a controversial discourse began in April 2015 with the tragic sinking of five boats in the Mediterranean Sea carrying nearly 2000 individuals who had hoped to reach Europe. This incident resulted in a sharp rise in attention towards human migration, as well as an international media hype and, ultimately, a mixture of regional and national debates vis-à-vis immigration, identity and security in most of Europe. What made the Refugee and Migrant Crisis (RMC) such a phenomenon was not the sheer numbers of individuals making their way to Europe, nor the seemingly ceaseless casualty reports it generated, but first and foremost the context in which it developed. Already in 2015, sensitivities towards foreigners-especially those of Muslim faith-were heightened in most of Europe. By then, the continent was attending to the complexities of the increasing frequency of Islamist-linked terrorist attacks since 2006, the 2008 financial crisis, the Greek debt crisis of 2010, the Crimea/Ukraine crisis of 2014 and the increasing support for right-wing, nativist political parties agitating European Union politics (European Union Terrorism Situation and Trend Report 2018). As Professor Claudia Postelnicescu (2016) stated, Europe, facing the RMC, was "at a crossroad, divided between the need to remain faithful to its core democratic values and freedoms, maintaining an area of freedom and justice and the need to protect its citizens against the new terrorism and the rise of nationalistic leaders and parties that require less Europe and more power back to the nation states" (Postelnicescu 2016). No freedom, however, has since been more challenged by this migration influx than the freedom of movement within Europe's internal borders as established by the Schengen Agreement.

i Claude Beaupre, Joint PhD candidate, Department of Political Science, University of Victoria, Canada, and Department of Contemporary History, University of Strasbourg. Contact: claudebeaupre@uvic.ca

ii Franziska Fischer, PhD Candidate, Department of Political Science, University of Victoria, Canada. Contact: ffischer@uvic.ca 
For a few states, the reintroduction of what should in theory be temporary border controls between European states has become a new status quo since 2016. Two main trends for reborderisation have emerged: controlling the flow of the RMC (Germany) and countering terrorist attacks (France). Both inherently linked trends with the result of challenging the principle of freedom of movement are connected to the label 'refugee,' a label that not only sparks fear, disdain and rejection from segments of the public but also fails to differentiate between the diverse identities of individuals who enter Europe. While some fall under the Refugee Convention definition of refugees (UN General Assembly 1951), many are loosely linked together by the term 'migrant', as that is the only characteristic that connects their journey to Europe. The newly constructed label refugee often combines all people entering Europe from the Middle East and Africa, without differentiating the broad range of backgrounds and motivations for migrating. 'Refugee' has become the new catchword for a potential danger that goes beyond the actual person in dire need of humanitarian support. As such, the frequent portrayal of these 'refugees' as security threats makes border security a tool with which to regain control over this perceived security threat.

While the media focus on the RMC arguably slowed down with the closure of the Balkan route and the implementation of the EU-Turkey deal in March 2016, which stemmed the tide of migrants entering Europe, and most recently with the respective border closures due to COVID-19, the immigration, identity and security debates remain to this day (Neske 2018). Albeit arguably not in the centre of public attention, the label 'refugee' remains an argument adduced in favour of keeping borders closed in the Schengen Zone. As Nail (2016) describes, recent global developments have led migration and terrorism discourses to feed off each other by relying on the same imagery of violence, danger, and warfare (Nail 2016). Consequently, it is not the aim of this article to debate whether the events of 2015/2016 merit the title of "crisis" be it migratory, humanitarian or other, nor is it to seek out the exact timeline of this so-called crisis. The goal of this article is to understand some of the elements which have led France and Germany to perceive the events of 2015 and 2016 as a danger to national security thereby revoking one of the core founding principles of freedom of movement that the European Union is built on. This paper thus sees the reintroduction of border controls rather as a tool to recreate the illusion of control over the perceived threats associated with the label 'refugee'.

In more detail, this paper argues that the label 'refugee' came about through a temporary consensus of the meaning of the word 'refugee' within the discourse that emerged as a result of the RMC in 2015/16, which motivated political calls for reborderisation. These measures often occurred in contradiction to European- wide legal provisions encoded in the Schengen Borders Code, the Treaty of the Functioning of the European Union and the Dublin System. In order to display the connection between the label refugee and border policies this paper is organized in three parts. First, it will outline the legal framework of the European Union regarding freedom of movement, migration and refugees. Secondly, it will delve into the meaning, or the connotation, of the label refugee, tightly connected to signifiers such as security threat, economic burden, and cultural disturbance, through a brief discourse analysis. Lastly, by outlining the historical and recent developments in both Germany and France in context to border policies, and their respective shift in perception of the label 'refugee', we aim to display how the label refugee in the public and political narrative has assisted France and Germany in taking on the same course of action: reintroducing borders controls. France and Germany are here chosen as case studies as they have pioneered the notion of freedom of movement within the context of the Schengen Zone and the EU which now stands challenged by the RMC.

\section{The Concept of Freedom in the Works-the Schengen Zone challenged by reborderisation}

In the early 1980s both France and Germany pioneered the notion of freedom of movement for "persons, services and capital" amongst EU Member States in what came to be the Schengen Agreement of 1985, building upon the Treaty of Rome of 1957 (Treaty establishing the European Economic Community 1957). The Schengen Zone (Schengen), refers to an area comprising 26 European countries, all of which belong to the EU with the exception of Norway, Iceland, Switzerland and Lichtenstein. The distinction between external borders of Schengen versus its internal borders is key to understanding how movement of goods and persons throughout is monitored. Once having been approved by an official point of entry into the area, any individual or item, irrespective of nationality, may cross any internal (i.e. national) borders within the delimited geographical zone without being subjected to further checks. By adopting Schengen, nation-states give away a portion of their ability to control the human flows within their territory by moving all their border control endeavours to a jointly managed organisation that patrols the external borders of the zone. The lack of internal border controls within Schengen allows individuals a wide array of countries from which to enter Schengen; some of which may have more lenient entry provisions and/or fewer resources to provide the level of control desired by other ratifying nation-states. As such, this agreement has raised concerns over the securitization of national space vis-à-vis the monitoring of human movement.

Patrolling human movement with Schengen depends largely on a visa-based entry system. Naturally, issuing 
visas is not a fool-proof solution to human migration, as irregular entries through sea and land routes bypass legal procedures and are hence impervious to official border controls. Indeed, while there has been a global trend to increase security in a post-9/11 world due to fear of illegal migration, terrorism and smuggling, international levels of illegal entry have gone unabated despite extensive efforts (Diener and Hagen 2012, 64). Throughout the RMC, for example, some men and women determined enough to enter Schengen found themselves subjected to increasingly creative smuggling practices such as Jet Ski trips from Morocco to Spain, parachute jumps from Turkish cargo flights, and in some more inventive instances, "some kind of self-made submarines” (UNHCR, 2017, 44). These imaginative and often precarious means of transportation are the end result of a pan-European system to further deter human migration by leaving asylum-hopefuls with limited options when entering Schengen. In order to address the worries surrounding freedom of movement throughout the area, additional provisions have been set in place to standardise the entries in and between Member States.

In 1999, the European Commission adopted the Common European Asylum System (CEAS), expecting EU Member States-and therefore the vast majority of Schengen states-to grant asylum to individuals who are deemed refugees according to the 1951 Geneva convention on the protection of refugees. It should be clarified that an asylum seeker to the EU is by definition someone who claims to be a refugee but whose claim has yet to be evaluated. As such, someone is deemed an asylum seeker for so long as their application is pending; hence not every asylum seeker will be recognized as a refugee, but every refugee is initially an asylum seeker.

The CEAS is responsible for the development of the Dublin System, which establishes that the Member State responsible for the examination of the asylum application is the first country-usually either Italy or Greece-in which the asylum-hopeful has first entered the EU (European Union, Council Regulation 2003). The reception and protection of applicants are viewed as a burden on receiving countries due to financial, administrative, social and political implications (CEASEVAL, Wagner, Perumadan, and Baumgartner 2019). This mechanism results in portal countries being significantly more impacted by migration to Europe than other countries creating an uneven bureaucratic pressure on those receiving more asylum applications than others merely due to their geographic positioning, such as Greece and Italy. Pries (2019) called this systemic inequality "a mechanism of organised non-responsibility" between Member States, and the minimisation of this practice is perceived as a pressing issue in the further elaboration of the Dublin System (Pries 2019, 4).
The lack of solidarity between the Member States manifested itself in the European Court of Justice Case that ruled against Poland, Czech Republic, and Hungary for Noncompliance with Migrant Relocation Obligations on April 2, 2020, suggesting a failure of the countries to respond to the emergency situation characterised by a sudden inflow of nationals of third countries and providing relief especially to Greece and Italy when faced with the exceptional burden of experiencing the highest numbers of asylum seekers throughout the European Union (Judgment of the Court [Third Chamber] 2 April 2020).

For the asylum seekers themselves, this first country of entrance clause means that their individual agencythat is the ability to decide where they actually want to go and wish to reside-is legally immaterial. This is especially problematic when taking into consideration the evidence of varying levels of treatment towards asylum seekers amongst Member States by both the UNHCR and the European Council on Refugees and Exiles, with some levels, bordering on unlawful negligence (Dublin Regulation 2008). As such, there is a higher sensitivity towards "asylum shopping" or "secondary movements" of asylum seekers within the EU. While not a new practice, the sheer numbers asylum seekers in the RMC has brought this issue to the fore of political debates. Secondary movements refers to the act of leaving the original country in which they arrived and had begun the process for asylum recognition according to CEAS regulation, to another Member State in which they plan to also seek legal protection (CEASEVAL Wagner, Perumadan, and Baumgartner 2019). The decision to do so is driven by a multitude of factors such as reception standards, the location of a diaspora, the wish for family reunification, the ability to speak the national language or, more simply, the desire to reside in one place rather than another. As of yet, there are no legal punitive consequences for secondary movement of asylum seekers, nor are there reliable data on the scale of the practice. In all likelihood, secondary movement offenders are likely to be simply returned to their first country of entry if caught. To this day there is no overarching system that would prevent asylum seekers from being moved from state to state -in or outside of the EU-resulting in the potentiality of asylum seekers being returned to unsafe grounds or their country of origin (European Parliament 2016). As such, there is a significant enticement for refugees and migrants arriving on European soil to avoid registering in portal countries and push onwards illegally.

According to the European Parliament more than 2.3 million illegal crossings were detected in 2015 and 2016, challenging a CEAS that was incipiently created to handle a small number of refugees and migrants (EU Migrant Crisis: Facts and Figures 2017).

Regional failure to create the much desired policy coordination, especially when faced with such trying times 
Borders in Globalization Review | Volume 1 | Issue 2 | Spring/Summer 2020

Beaupre and Fischer, "The Label 'Refugee' and its Impacts on Border Policies"

as the RMC, resulted in open discontent and a divide in the internal political discourse of the Union. Ultimately, it acted as a catalyst for the reborderisation of the Schengen Zone, leading previously abiding Member States to derogate from the Schengen Agreement to focus instead on national efforts to contain and control migration within their sovereign space; thus, acting against the norm of freedom of movement codified within the European legal documents (European Parliament 2016)

While discouraged, reintroducing border controls along internal Schengen borders remains within the rights of Member States. Article 25 et seq (25 to 35 ) of the Schengen Borders Code provides these sovereign Member States with this possibility, "in the event that a serious threat to public policy or internal security has been established" (Temporary Reintroduction of Border Control, European Commission, 2019). Making use of these articles is always meant to be a last resort, proportional andmore importantly-short-lived. This was reiterated in 2017 when the European Commission published a proposal for an amendment to the Schengen Borders Code giving Schengen states greater leeway when addressing threats to national security (European Parliament 2016).

Since 2015, however, border controls activities throughout the internal Schengen borders have become a problematic status quo for many Schengen-abiding countries. Between September 2015 and December 2019, according to the European Commission (2019), border controls have been reintroduced and prolonged almost 50 times (European Parliament 2016). Prior to the RMC, contrastingly, there had been only 36 cases of reintroduced border controls since 2006 , most of which were linked to ensuring the safety of high-profile international meetings. Since, however, the "serious threats [from the RMC and instances of terrorism] compelled some Member States to prolong reintroduced border control several times until the exhaustion of the legal time frames" supported by Article 25 et seq (European Parliament 2016). The reintroduction of border security within the Schengen zone, especially exemplified by its two founding countries, is worth exploring. After all, the role of external state borders as demonstrated by Diener \& Hagen $(2012,64)$ is intrinsically linked with its perceived security, which leaves one to ponder the implications of this increasing borderisation. If deemed safe to do so, a "good" border region may be viewed as permeable to varying degrees, equipped with open communications, formal demarcation agreements, standing boundary commissions, accessible transportation links, and a minimal military or police presence while remaining capable of stopping harm from entering such as terrorism and drug trafficking (Diener and Hagen 2012, 66). Indeed, the Schengen zone in its original format was made up of predominantly "good" borders.
Some border theorists have argued, moreover, that a permeable border is simply a remaking social of categories of belonging, one linked with the idea of citizenship and otherness (Anderson 1997; Diener and Hagen 2012, 83). Such a logic would further the dichotomy between the perception of terms such as immigrants and refugees as negative and terms such as cosmopolitans and global citizens as positive. This is, of course, a generalization, as there are different ways within any given society to perceive refugees. A refugee is legally defined by the 1951 Refugee Convention as a "person who, owing to well-founded fear of being persecuted for reasons of race, religion, nationality, membership of a particular social group or political opinion, is outside the country of his nationality, and is unable, or owing to such fear, is unwilling to avail himself of the protection of that country" (UN General Assembly 1951). Even though this official definition carries important signifiers such as 'persecution' and 'well-founded fear' that could provoke an empathic reaction and shape the discourse through its narrative, the development of the refugee discourse nowadays has taken a different turn. Following the Second World War, the implications of persecution due to race and religion had moulded contemporary reality. Nowadays, however, as we demonstrate, the label 'refugee' evokes a different reaction within the public opinion and narrative, which is no longer predominantly empathetic, but rather defensive and/or cautious.

Naturally, the RMC did not only involve refugees. Not all who were making their way to Europe during 2015 and 2016 did so out of fear from being persecuted. During both years, the top nationalities applying for asylum to the EU were: Syrians, Afghans, Iraqis, Pakistanis, and Nigerians. All of these countries have their own unique turmoil and not all who left these did so out of purely fear-based reasons. While many undoubtedly fell under the Geneva convention definition of refugees, others fell under the description of an economic migrant, "[a] person choosing to move not because of a direct threat of persecution or death, but mainly to improve their lives by finding work, or in some cases for education, family reunion, or other reasons" (UNHCR 2019).

Moreover, the term economic migrant implies that such an individual aims to join the workforce of its receiving country and become an often-times permanent member of the local society. These two elements, however, are not well received by those who fear not only that these migrants might "steal" available jobs, impacting their own or their peers' chances of employment, but might eventually come to affect the local culture with their own diverse backgrounds.

Using these terms correctly is vital to understanding the reality of individuals, especially for refugees as it creates confusion and takes away attention from these people who require-and are entitled to-recognised legal protections. By merging these two terms, the 
fear that stems from migrant arrivals are transferred to refugees. For the purpose of this discourse analysis, this paper will focus on one predominant narrative within some societies that tend to perceive refugees negatively.

\section{The Refugee Discourse: An Interregnum of Meaning}

Public discourse is a constructed set of truths through narratives created by social norms and values, by representations of reality and social identity and by national and supranational legal norms. Discourse analysis theory, rather than negating the presence of facts, will gain understanding of its meaning correlating the linguistic, social, political and economic input within a discourse and thus become understandable. Jørgensen and Philipps define discourse as a "form of social action that plays a part in producing the social world-including knowledge, identities and social relations-and thereby in maintaining specific social patterns" (Jørgensen and Phillips 2002, 5). Thus, discourse is not only a reality-creating tool but also a catalyst for action within this reality. Therefore, if different discourses catalyze different actions, those actions may enter into conflict. In that sense, discourse may also be understood as a guideline or instructions on how to act in a specific situation. As every situation is unique in regard to its context, the guidelines or instructions are most likely always interpreted differently, accordingly to the context. Thus, discourse leads to change in the social world, as through the changing guidelines or instructions it forms identities, but also organizes behaviour and relationships according to these identities. An example of this is the national discourse that forms the collective identity of society within a nation-state around distinct cultures. Further, it creates instructions on how to relate to other nations or other groups such as migrants. Kølvraa argues that discourse then also organizes "certain objects as representing the category 'national culture' and interaction with these will be subject to other rules-other standards of 'appropriate behaviour"' (Kølvraa 2012, 20).

According to Laclau and Mouffe's interpretation of discourse theory, discourse offers or "establishes a closure, a temporary stop to the fluctuations in the meaning of the signs. But the closure is never definitive" (Laclau and Mouffe 1985 [2001], 21). On the one hand, it means that meaning or a 'truth' within a reality is constantly changing and transforming but a discourse establishes an interregnum in this constant change (Laclau and Mouffe 1985 [2001], 113-4). On the other hand, it allows observing and understanding social phenomena through discourse analysis only temporarily and insists on a constant re-evaluation and observation of the transformation of meaning.

The representation of an individual or a group of people within a physical and abstract space such as society within a territory plays a significant role in how this individual (or group) is perceived and understood. However, this is merely one side of the discursive power of representation, as it also has a profound effect on how an individual (or group) positions itself on an emotional level within a physical or abstract space. Physical space can be understood as territory, "based on two components: a frontier that separates outside territories and the lands inside" such as the nationstate (Middelhoff 2015, 1). Thus, the societal and historical context of each nation-state plays a crucial role in how representation is perceived and reproduced in the public. Consequently, frames and labels have to be evaluated in the context in which they are constructed and produced and are not interchangeable nor generalizable, but highly subjective, arbitrary and unstable interregnums of meaning within certain situations. The RMC, for example, presents such an interregnum of meaning in the refugee discourse in both Germany and France respectively. To understand political actions to close borders during the RMC in France and in Germany as part of a response to public discourse of refugees, it is helpful to explore labels and frames as cornerstones of public discourse in more detail.

\section{Labels creating Identity}

Part of understanding an identity means understanding how one or many may fit in with other groups of people which closely links to its social construction. Creating a narrative and imposing it on refugees happens within the imagination. Metaphorically speaking, through the creation of an imagined 'space' within their imagination the population of a sovereign regime is able to homogenize and index flows of people that are in no way homogeneous in their identity, and thus create a homogenized narrative that is then imposed on the migrants. Roger Zetter identifies the 'label' refugee as a 'convenient image,' one "which is driven by the need to manage globalized processes and patterns of migration and forced migration in particular" (Zetter 2007, 172). Thus, the label refugee adheres an interpretation that carries a narrative, as a society has a very clear image of the story of 'a refugee'. The homogenous refugee label stands therefore in contrast to the actual very heterogeneous identities due to different memory and imagination of homeland. Zetter argues that "we deploy labels not only to describe the world but also to construct it in convenient images" (2007, 173). He further argues "that labelling was not just a highly instrumental process, but also a powerful explanatory tool to explore the complex and often disjunctive impacts of humanitarian intervention on the lives of refugees" (2007, 173). In other words, supposedly knowing their story seems to suggest knowing what they need, where they belong and who they are. In that sense, labels always carry an agenda. Further, "[t] hey are the tangible representation of policies and programs, in which labels are not only formed but are 
Borders in Globalization Review | Volume 1 | Issue 2 | Spring/Summer 2020

Beaupre and Fischer, "The Label 'Refugee' and its Impacts on Border Policies"

then also transformed by bureaucratic processes which institutionalize and differentiate categories of eligibility and entitlements. In this way, labels develop their own rationale and legitimacy and become a convenient and accepted shorthand" (Zetter 2007, 180). The argument is about the tool of a regime of territorialization to control social flows, creating a label that supports the separation of the legitimate and the rejected. Therefore, the label refugee acts as a tool to not only separate from non-refugees, but one that may be used to create a binary representation of identity; either one belongs in a certain space or one does not.

This us-versus-them connotation in turn triggers a feeling of apprehension. Zembylas identifies these "[f]eelings of resentment and hatred, [which] are distributed through discursive practices which come to signify the danger from mixing with them; they threaten our identity and mere existence. Thus, it is emotion discourses and practices that work to constitute who the 'victims' and the 'victimisers' are" (Zembylas 2012, 470).

Drawing on Ahmed (2004), Zembylas observes that "emotional encounters with others create boundaries or deconstruct such boundaries" (2012, 469). Thus, the label 'refugee' is connected to a person out of its place, outside of its sphere of belonging such as a nation-state and relocated in someone else's sphere of belonging. The notion of belonging is entangled with a defined space or territory and the label 'refugee' suggests a transgression of this territory; a transgression apt to trigger resentment, fear and/or outright aggression.

While this transgression happens within an abstract and imaginative realm, the response that was witnessed since 2015 following the RMC was tangible. It resulted in calls for political action to securitize against this constructed threat and ultimately the closure of national borders. Recently, the Schengen-based freedom of movement has been interrupted by many of the ratifying Member States. Germany and France are here used as prime examples of the two identified reasons given for reintroducing border controls: in response to terrorism and to control the migrant flow of the RMC. In both instances, 'closing' the borders was encouraged by popular demand in order to regain control, or at least the perception thereof, demonstrating the change in discourse towards refugees and migrants. This next part will display empirical findings of France and Germany and their respective political responses to the perception of refugees.

\section{The Fear of Terrorism-Empirical Findings in France}

Since late 2015, there have been two main security reasons cited by Schengen countries when reintroducing "temporary" border controls (Luecke and Breemersch 2016, 6). The first, linked with the rise in terrorist incidents throughout the continent, is closer to the traditional idea of state security in a post-9/11 world. This reason was utilised by France (2015-2016) and Belgium (2016) in the aftermath of terrorist attacks (Luecke and Breemersch 2016, 7). Many Schengen states, such as Austria, Denmark, Germany and Sweden (as well as Norway, a non-EU Schengen state) justified their rebordering beyond the two-year limit on the basis of Article 29 of Schengen Borders Code (SBC), citing "serious deficiencies in the carrying out of external [Schengen] border controls", forcing them turn inwards and unto themselves. No doubt also influenced by Article 29, France is, however, the only Schengen country to have restored-and maintainedcontrol over part of its internal borders with the view of protecting itself from persistent terrorist threat (Hamon and Fadier 2018). It made use of the SBC to bring back checkpoints ID verification to try apprehending the involved parties and keep further potential threats from coming in.

These security measures have long gone past the traditionally allocated time due to not only a two-year state of emergency but also tangible legislative reforms. France claimed it was lawfully enabled of doing so in accordance to article 27 of the SBC, which allows for a derogation from the fundamental principle of free movement of persons upon "the existence of a genuine, present and sufficiently serious threat affecting one of the fundamental interests of society" (European Parliament 2016). Following the November 2015 attacks, France initially made use of Article 25 to reintroduce temporary controls along all of its internal borders continuously-with the only brief exception of July 15th 2017 to November 1st 2017-each time citing its terrorist attacks for the reintroduction of controls. It also made use of Article 22's insistence on proportionality of response, claiming that these were indeed exceptional times and that their actions were proportional to the threat at hand, in addition to being "exceptional" and "necessary" as required by Article 25 itself (European Parliament 2016).

It must be added moreover that this proportionality element was not so much based on the rebordering efforts being necessary to complement the ongoing counterterrorism state-efforts per se, so much as being deemed necessary in sight of believing terrorist attacks more likely during these times (Hamon and Fadier 2018). This distinction between a state mobilising in an immediate aftermath against actual attacks-as supported by the SBC-versus choosing to remain in a state of anxiety towards these incomers embodying potential threats while having no actual end date in sight is key.

Prior to November 2015, France had only ever made use of Article 25 et seq. on nine separate occasions since 2006, three of which were in reaction to brief civil society protests within the country, and the 
remaining ones linked to high-level international summits (Regulation (EU) 2016/399). Following the attacks however a state of emergency was declared. It was then renewed six times by 2017, after which President Macron replaced it with the highly contested new counterterrorism law. Not only does this explain the small gap in temporary border controls between July and November 2017, but it also entails a new era of security within the country, a sort of return to pre-Schengen times. No longer are the "temporary" border controls emplaced due to specific terror events, such as the ones in Paris on the 13th and 14th, 2015 and July 14th , 2016 in Nice; they have since been vaguely justified under the umbrella of "persistent terrorist threat" to the country (European Parliament 2016). It should be noted that France's decision to continue border controls past the maximal six-month period elaborated in the SBC stands in outright violation of Article $25 \S 4$ (Hamon and Fadier 2018).

While Article 29 of the SBC could have allowed border control extension up to two years, France never received the necessary European Council recommendation to bring it into effect. Even with this disregard for EU legislation, France's actions have not incurred a legal response. France, in fact, is not unique in choosing to retain its borderisation efforts. Its decision of acting independently from the SBC highlights a major problem Schengen faces to this day: how will the EU break away from this newfound borderised status quo and put a stop to the systematic renewals of controls along internal borders?

This perception of persistent terrorism and the resulting new counterterrorism law-similar to USA's Patriot Act-are now a permanent continuation of the measures put in place during a State of Emergency. They ensure "daytime military patrols in major cities, a major investment ramp-up into domestic intelligence collection and the creation of a new anti-terrorism task force [and] grants police and investigators extensive powers to raid, detain and question terrorism suspectsmaking many special provisions permanent" (Vinocur 2017). These latter "special provisions" to control and outright exclude migrant entrance into the country have been highly criticized for discriminating against France's established Muslim minority and promoting Islamophobia at large (Vinocur 2017).

It should be added, moreover, that Muslim-focused racial profiling in France is not intrinsically linked to the RMC, nor is it limited to the aftermath of recent terrorism trends, but is rather the fallout of French migration and colonial history. Like most of its European counterparts, France has a rich history of immigration from its former colonies. By the 21st century, nearly six percent of the country boasted foreign roots, a portion which has remained constant since 1975 (Popkin 2020). While some immigration came from neighbouring European states, a large majority of them migrated from France's former colonies, notably Muslim Northern and Western Africa. In 2019, this has come to mean that, while France does not collect census data, an estimated nine percent of the French population practiced Islam; the highest percentage in Europe (Popkin 2020). This religious minority, however, is known to experience unfavourable economic and social conditions. Like many marginalised migrants populations, they experienced "higher unemployment than the rest of the population; a higher incidence of accidents on the job; housing problems, such as being isolated in large, high density housing projects on the outskirts of big cities that were slowly deserted by native French families; problems at school; and high levels of crime and unrest" (Laurence and Vaisse 2012, 31). It would be inaccurate to speak of a ghettoization of France's immigrant populations. While some banlieues or cités might have a high percentage of Muslim dwellers-and indeed are discursively associated with them-no single area is purely inhabited by a single ethnic origin or religion (Laurence and Vaisse 2012, 36).

This sensibility towards those of Islamic faith throughout the country while not new became blatantly apparent in the aftermath of the November 2015 attacks. It peaked when a Syrian passport was found near the body of one of the aggressors. Unsurprisingly, this led many to link the threat of Islamic-extremist terrorism to the ongoing RMC despite all of the attackers holding either French or Belgian Nationality (Farmer 2016). The passport, in fact, had been stolen and had belonged to a completely unrelated party, an asylum-seeker who had arrived in Greece a few weeks earlier. Even so, the affiliation remained, and while not all incomers involved in the RMC originated from Syria (only 30\% of them actually did), the discursive association of the $\mathrm{RMC}$ incomers with notions of religioun-based violence and threats became an easy one to make (European Parliament, Eurostat 2018). Naturally, refugee perception in France is not merely linked to this one incident but stands testimony of years of discursive elaboration of a post-9/11 world. In a 2019 report to the European Parliament, it was demonstrated that public opinion, media coverage and political debate had jointly securitised the discourse on refugees, especially in rural France and right-wing political supporters (Fine 2019).

As was the case in many other states, a significant portion of the hype from the RMC was fuelled by far-right nativists, notably the Front National under Presidential-Candidate Marine Le Pen. Thus, the RMC was a convenient tool with which to drive forward their political platform. In September 2015, prior to the November Paris attacks and a few months past the Charlie Hedbo shootings, Le Pen stated in an election rally that the RMC was comparable to the barbarian invasion of the 4th century and that France "must immediately stop this madness to safeguard [its] social pact, freedom and identity" against this new prevailing 
Borders in Globalization Review | Volume 1 | Issue 2 | Spring/Summer 2020

Beaupre and Fischer, "The Label 'Refugee' and its Impacts on Border Policies"

threat (Kent 2015). With the pre-existing stigma associated with France's Muslim population, linking the RMC with the need to reintroduce internal border controls was not a difficult task. It would be unfair, however, to blame this discursive association solely unto one political faction, no matter how loud. Indeed, similar securitised rhetorics have been known to be uttered by Former President Hollande who stipulated in 2016 that his country had "a problem with Islam" (Willsher 2016).

The representation of the RMC through various channels, such as the media and political rhetoric has fallen on fruitful grounds in France. This was the result of the country being historically and socially preconditioned to apply a homogenous social identity to a group of people such as 'the refugees', connecting them to violence and crime and disregarding their vastly different backgrounds, historicities and identities. This homogenous perception allows the right wing and populist political spectrum to utilize the rising public concern to drive forward their political agenda by offering a response to the public demand that goes beyond mere border controls.

\section{A Shift in Perception-Empirical Findings in Germany}

The second trend of reborderisation identified is linked with curbing the flows of refugees and migrants entering Europe not out of fear from religious zealousness but indeed to maintain order. It depicts a shift in perception and a heightening of sensitivity towards migration; viewing the influx of foreigners as threats to security and the economy, fearing unrest and drainage of state resources. This trend was perceived in the Scandinavian countries, Germany, and Austria as means of reducing or at least managing the influx of refugees and migrants (Luecke and Breemersch 2016).

Unlike France who made use of Article 25 et seq. of the Schengen Borders Code to reintroduce temporary controls along all of its internal borders because of terrorist threats, Germany reintroduced theirs as means of controlling the flow of refugees and migrants heading their way from the Balkan migratory route. Faced with unprecedented levels of asylum claims and illegal migration, from September 2015 onwards, the country reintroduced border controls, a measure that was prolonged eight times and is still in place today. While France increased its border control along all its national borders, Germany refrained theirs to merely one border: the one shared with Austria. This measure was recommended by the European Council as of May 2016 "to respond to the serious threat and to safeguard public policy and internal security resulting from the secondary movements of irregular migrants" (European Council 2018). It was similarly recommended to Austria, Denmark, Sweden and Norway. It is important to differentiate that this 'recommendation,' was not made due to the large-scale arrival of migrants per se. Indeed, it could not in accordance with Article 26 of the Schengen Border Code which states that "a large number of third-country nationals should not, per se, be considered to be a threat to public policy or internal security". Germany's decision instead focused on mitigating secondary movement of asylum seekers with the EU (European Parliament 2016).

This heightened number of secondary movements during the RMC finds anchoring in the organised non-responsibility promoted by the Dublin System. It resulted in Greek and Italian authorities becoming overwhelmed and left with no choice but to allowand at times blatantly encourage-arriving crowds to make their way to other EU states without identifying or registering them in accordance with regulations (Joannin 2016). To mitigate the effects of organised non-responsibility, and long before the RMC, the European Court of Justice had already ruled that Member States were allowed to manage asylum applications of anyone who had entered the EU via another state if said state had subpar asylum reception standards. Therefore, Germany receiving refugees and accepting asylum applications of persons who had entered the EU via another country was not a violation of European or national law. Indeed, Greece and later Hungary as prevalent countries of first entry, had been deemed inadequate in their services to asylum-hopefuls by the German courts and the European Court of Justice (Versteegh 2015).

Reborderisation in relation to RMC asylum control came about more predominantly in late 2015, early 2016 when some EU Member States re-implemented widespread ID checking along their borders. In Germany more specifically, Chancellor Angela Merkel made international headlines in August 2015 and again in September when she publicly announced Germany's readiness to accept 800,000 refugees into the country and adopted an open policy towards them (Joannin 2016, 3). This was especially geared towards Syrian nationals, as she stated in August 2015 that "Syrians can stay in the country while applying for asylum, rather than being turned back to the EU country where they first arrived" (Mcdonnell 2016).

Following the mass exodus during WWII hostilities, Germany has since adopted a Willkommenskultur, or welcoming culture, towards refugees (Mcdonnell 2016). This attitude, joined by the fact that the country has boasted Europe's biggest economy and a low unemployment rate for many years has resulted in many aspiring to migrate to it. McDonnell suggests that "some of the country's most prominent backers of refugee-friendly policies are industry groups, who have argued that migrants are needed to help fill a labour shortage [and as such] Germany has a relative bounty of social services directed toward migrants: Subsidized housing, education, health care, and so on, and a streamlined process for filing immigration paperwork" 
(2016). This has greatly aided the widespread perception that Germany is a safe and accessible country whose liberal asylum laws act as a pull for new arrivals, a reputation bolstered over time by diaspora networks particularly from the Middle East (Trines 2017).

Anti-refugee narratives in Europe would put forth that Merkle's "we will manage" RMC-related statement encouraged and propelled the stream of asylum seekers coming to Europe, however, a study conducted by Ludger Pries (2019) suggests otherwise. He argues that "empirical evidence of the impact of Merkel's dictum on the actual refugee movement and decisions leads to a clear conclusion: there was no substantial, measurable impact of Merkel's 'We will manage' on the volume and reasons of refugees' decisions to orient towards Germany" (Pries 2019, 7). Nevertheless, Merkel received tremendous public backlash for her liberal approach to immigration and asylum seeker regulations. This backlash paired with falsely represented instances connecting refugees to violent attacks in the media supported the creation of a label 'refugee' that turned into ammunition for rebordersation efforts.

This phenomenon could be observed through the presentation of the attack in a Munich shopping Mall, the attack in the Berlin Christmas market and the sexual harassment attacks in Cologne on New Year's Eve. In all cases the first reaction of the media was to imply a refugee connection, often with a question mark that was overlooked and ignored by the public and political eye. The Huffington post suggested the men responsible in Cologne had arrived days prior to New Year's Eve as part of a new wave of refugees. Further along in the same article, however, the BKA (Federal Criminal Police Office of Germany) is quoted saying the suspects had long been under their radar for previous offences, rendering their arrival timeline questionable at best (Kosch 2016). Furthermore, the suspects were later identified as originating from North Africa, making them unlikely to qualify as refugees. Thus, they should not be referred to under the same legal migration designation. Similarly, the Spiegel also advanced that refugees were among the suspects while also stating a few lines further that there was no actual evidence that would prove the offenders to be refugees (Übergriffe an Silvester 2016).

While these might be merely two examples, they remain powerful ones. Even if both rectify their initial assumption, the immediate connection to refugees as an emotional reaction to a violent incident lingers with the public perception. This is not to say that there have not been incidents including refugees and violence against other refugees and/or non-refugees in Germany; indeed it would be false to suppose as much. These examples simply attest to the discursive label attributed to refugees and supports the widespread connotation that every person that appears to have a migratory background falls under the 'refugee' umbrella. This negative and unruly perception of 'refugees' in turn leads to them being scapegoated should any future incidents occur. Incidents against refugees are often just dismissed by arguing that it was a separate incident carried out by extremists, which are not perceived as a recurring and growing national issue and thus not acknowledged as a national recurring and growing trend (Middelhoff 2015). The uncertainty of the public of being unable to grasp the 'grey mass' that is constructed through that narrative of the label refugee thus translates into an oversimplified picture of the situation that allows making sense of a situation, however failing to grasp the intricacies.

Appadurai identifies this uncertainty as a "crisis of legitimation" (Appadurai 1996) of the nation-state through migration, arguing that "states lose their monopoly over the idea of nation" (Appadurai 1996). One way of protecting the nation is the reintroduction of a physical space of the nation-state through borders. So, even though there was a transgressive accession of that space, transgression in the sense of "to cross a line, to step across some boundary or move beyond" (Wolfreys 2008, 3), through reborderisation, the notion of control, or at least the illusion of control is handed back to the sovereign regime.

The influx of refugees in Germany has also been met with increased Islamophobia. In 2013, for instance, the anti-immigration party, Alternative für Deutschland (AfD), was founded with its leadership claiming that the Islamic faith is incompatible with the German constitution. It championed measures to stop the flow of Muslim immigration into the country, stating that they could not integrate and would eventually remove-and replace-the existing population within the country's borders. Research evidence suggests many Germans hold negative perceptions of Muslims. In addition, since October 2014, xenophobic and anti-Muslim marches led by the Patriotic Europeans Against the Islamization of the West has attracted as many as 17,500 supporters. Hate groups are reportedly prevalent among them and some have characterized the movement as "pinstriped Nazis". Indeed, research evidence suggests many Germans hold negative perceptions of Muslims (Abdelkader 2019). In 2016, approximately 40 percent supported a Muslim ban on immigration and 60 percent believed Islam has no place in the country. A 2015 study found anti-Muslim sentiment to be pervasive-transcending income, education levels and political affiliation. It revealed that 57 percent of Germans view Islam as a threat, and 61 percent of Germans believe it is incompatible with Western values (Abdelkader 2019).

In 2017, Germany had approximately three to four million Muslims, nearly 5 percent of the overall population, representing the second largest Muslim population in Europe, after France. No doubt this statistic was affected by the one million individuals immigrated 
Borders in Globalization Review | Volume 1 | Issue 2 | Spring/Summer 2020

Beaupre and Fischer, "The Label 'Refugee' and its Impacts on Border Policies"

to Germany from Muslim-majority countries such as Syria, Afghanistan, and Iraq and the subsequent chain-migration. For nearly three decades, Germany has maintained nearly 30 percent of all asylum claims in Europe demonstrating a pulling effect that has yet to be matched by any of its EU counterparts.

Like France, such anti-immigration discourses, however, are not limited to migrants and refugees being considered security threats. At times, they are referred to as a burden to the host society and/or something to be wary of. The latter was cited most frequently after the 2016 "Cologne attacks" in Germany, where "as many as 1,000 women had been sexually assaulted-groped, robbed, intimidated and separated from their friendsat Cologne's central train station on New Year's Eve" (Richards, 2016) by men of North-African and Arab origin. This attack was perceived by some as ultimate proof that the male migrant and refugee newly arrived to the country came "from countries where they have no respect towards women", proving themselves to be unlikely to conform to the local culture by "doing what they want, and taking anything they want" (Gümplová 2016). In response to the Cologne events, local authorities issued warnings to women to avoid certain places, towns barred migrants from entering swimming pools, thousands of police personnel were readied to patrol carnival marches, and pink security zones for women were proposed (Gümplová 2016).

For the refugees and migrants newly arrived into the country and for German citizens of North African or Arab origins, this turn of event was worrisome. While in summer 2015, masses of ordinary people greeted arriving migrants and refugees at the train stations, the Willkomenskultur seemed greatly diminished after the attacks, resulting in an increasing support for far-right parties in Germany. This came at a time when Germany had registered a sharp increase in vandalism of refugee facilities and asylum seekers' accommodations since mid-2015 (BKA-Statistik 2016). The 'Süddeutsche Zeitung', a German newspaper, counted more than 3500 violent incidents against refugees outside of refugee accommodations, including men, women and children, alongside attacks on volunteers helping refugees (Mehr als 3500 Angriffe auf Flüchtlinge 2017). The motivation for attacks on accommodations and on individuals stems from national socialist and right-wing belief systems, leaving one to wonder about the eventuality of many more unreported ones. Germany, it seemed, merely a few months after publicly opening its borders to Syrian refugees, was losing public support for Chancellor Merkel's initiative by calling instead for limits on immigration such as caps on numbers of incoming refugees, limits on welfare benefits, the return of economic migrants, and the control of borders.

But how can we understand such drastic developments that seem to step-by-step dismantle one of the core values that the European Union is built upon: freedom of movement? The rising public concerns connecting the influx of refugees to terrorist threats and economic burden puts pressure on political actors. The oversimplification of the situation and the reduction of the large variety of different groups and individuals entering Europe to a few labels creates a discourse that ultimately is the platform for political actors to take action.

\section{Analysis of Findings and Conclusion}

The reception and accommodation of refugees in France and Germany was met with mixed emotions. For some, the RMC was met with tremendous public support and a positive attitude. For others the RMC equated concerns over security, resources and cultural differences; such notions were voiced by PEGIDA and the Yellow Vests movement to some extent, as well as political narratives stemming from the AfD and the Front National. Dissenting voices in both countries had clear expectations of their political leaders, containing and securitizing the refugee influx and thus ensuring national security. Ultimately, this came to be expressed through the reintroduction of border controls.

Germany and France, the two founding members of the EU and initiators of the establishment of free movement through the Schengen Agreement, have responded to the influx of refugees since 2015 in a similar fashion by accommodating these demands. Reaching this crucial step in responding to a perceived security threat through the arrival of refugees facilitated the representation of the RMC through various channels, such as the media. The label 'refugee' was redefined, connecting it to signifiers threatening national security, such as terrorism and violent attacks on the public, thereby triggering a discourse change in meaning and consequently a shift in the public reaction towards the new social identity of refugees. This label refugee is now being applied to not just refugees, but to every migrant with a foreign-and especially Islamic background. A perception was created that does not reflect reality, however, constructs a scenario in the public's imagination that presents a transgression of space and a threat to national security. In order to regain control over the transgression into the public sphere of belonging, the European Union witnessed a territorial response in closing the border-a tool to ease the mind of the people rather than to regain actual control over the perceived threat. Both France and Germany reacted in similar ways, though their respective paths to this response differed based on their societal and historical contexts. The basis for this development, however, can be found in the legal regulations that the European Union put in place, that have failed to create a coherent and appropriate framework to deal with the influx of refugees since 2015, and still fails to deal with the aftermath to this day. 
The Schengen Agreement in combination with the Treaty of the Functioning of the European Union and the Dublin System provides provisions and guidelines on how to deal with an influx, or a crisis on a theoretical level. In practice, however, the provisions fail to adhere to national belief systems concerning the needs of their national spheres. These needs include demands for greater security concerning terrorism and economic burdens. In theory and within the legal provisions these norms ought to be diffused through their appeal to the Member States of the European Union. In practice, the legal norms of the European Union are rhetorically extremely vague, which leaves enough room for interpretation of the Member States to pursue their own interest. Thus, in a situation of conflict between the European Union legal frameworks versus a nation-state legal framework, instead of action for the greater good of the Union, the Member States act for their own benefit. This can be observed through the behavior of the Member States, resulting from the influx of refugees and the efforts of reborderisation in order to regain at least the perception of control and securitization of national spaces. It appears to be a mere perception of control rather than actual control when closing the border, as no policy or border control can ever be truly a match to human ingenuity-true for both asylum seeking and for terrorism.

In both cases, Germany and France the created identity of refugees was utilized by right-wing and populist political actors to drive forward a national and Eurosceptic narrative. Thus, Germany and France face common challenges. In both cases there is the tendency of Eurosceptic or Europhobic populist forces to draw political capital out of the refugee crisis in the domestic political arena. Right-wing populism is particularly prone to resort to this issue as immigration and borders touch the very heart of national identity and sovereignty respectively. Right Wing political groupings brought considerable pressure to bear in the run-up to the 2017 general elections in both France and Germany (Koenig 2016, 2).

It remains to be seen if easing the public's mind through border controls will result in a successful campaign of right-leaning and populist political narratives, or if it the public will move away from demanding border controls, either moving on to a different mode of regaining control, or the perception thereof, or resulting from a new shift in discursive understandings of refugees and migrants. Either way, representation of the situation will play a crucial role and will remain a key facilitator in how the public will perceive the situation and consequently react to it. The driving social force of public opinion is thus heavily influenced by representational tools such as labelling, which may be utilized or manipulated by political actors in order to further their agenda. Thus, moving forward when addressing the RMC, it remains crucial to understand the construction of the discourse behind public demands, such as increasing border controls, in order to evaluate the significance of such tremendous political actions. France's and Germany's actions, however, are not unique in choosing to reinvigorate its borderisation efforts, and indeed a major problem Schengen faces to this day has been how to put a stop to the systematic renewals of controls along internal borders.

\section{Works Cited}

\section{News Media}

BKA-Statistik. December 28, 2016. "Mehr als 900 Angriffe auf Flüchtlingsheime", Tagesschau, Inland. https:// www.tagesschau.de/inland/bka-fluechtlingsunterkuenfte-statistik-101.html

Blickle,Paul.etal.December4,2015."ViolenceAgainstRefugees: Germany in flames", Zeit. https://www.zeit.de/politik/ deutschland/2015-11/anti-immigrant-violence-germany

Farmer, Ben. March 18, 2016. "Who is Salah Abdeslam and who were the Paris terrorists? Everything we know about the Isis attackers", The Telegraph. https://www.telegraph. co.uk/news/worldnews/europe/france/11996120/Parisattack-what-we-know-about-the-suspects.html

Kent, Simon. October 6, 2015. “Le Pen: Europe's Migrant Flood Equals 'Barbarian Invasions of 4th Century"', Breitbart. https://www.breitbart.com/europe/2015/10/06/le-peneuropes-migrant-flood-equals-barbarian-invasions-4thcentury/

Kosch, Lea. June 9, 2016. "Köln-Attacken: Silvester-Täter kamen mit Flüchtlingswelle nach Deutschland", Huffpost.

"Mehr als 3500 Angriffe auf Flüchtlinge; Süddeutsche Zeitung, Fremdenhass". February 26, 2017. Home Politik Flüchtlinge. https://www.sueddeutsche.de/politik/fremdenhass-mehr-als-3500-angriffe-auf-fluechtlinge-imjahr-2016-1.3395560

Middelhoff, Paul. und Karte der Gewalt. August 26, 2015. “Über 500 Angriffe gegen Flüchtlinge und ihre Unterkünfte zählte die Polizei allein in diesem Jahr. Wo leben sie besonders gefährlich?" Politik, Flüchtlinge; Zeit Online. https://www.esf-querschnittsziele.de/suchergebnis-detail/article//karte-der-ge.html

Mcdonnell, Tim. September 8, 2016. "Why So Many of Europe's Migrants Have Their Hearts Set on Germany", Mother Jones. https://www.motherjones.com/politics/2015/09/ heres-why-all-european-migrants-want-go-germany/

Richards, Victoria. February 11, 2016. "Cologne attacks: What happened after 1,000 women were sexually assaulted?" The Independent. https://www.independent.co.uk/news/ world/europe/cologne-attacks-what-happened-after1000-women-were-sexually-assaulted-a6867071.html

"Übergriffe an Silvester: Wer sind die Verdächtigen von Köln?" January 8, 2016. Panorama; Spiegel Online. https://www. spiegel.de/panorama/justiz/koeln-nach-silvester-attacken-fluechtlinge-laut-polizeigewerkschaft-unter-verdacht-a-1071005.html

Vinocur, Nicholas. October 31, 2017. "New French anti-terror law to replace 2-year state of emergency", Politico. https:// www.politico.eu/article/new-french-anti-terror-law-to-replace-2-year-state-of-emergency/ 
Borders in Globalization Review | Volume 1 | Issue 2 | Spring/Summer 2020

Beaupre and Fischer, "The Label 'Refugee' and its Impacts on Border Policies"

Willsher, Kim. October 12, 2016. "Francois Hollande: France has a 'problem with Islam'”, The Guardian. https://www. theguardian.com/world/2016/oct/12/francois-hollandefrance-has-a-problem-with-islam-french-president-booknicolas-sarkozy-little-de-gaulle

\section{EU Regulations}

Ammirati, Annapaola. December 8, 2015. "Open Immigration”. What is the Dublin Regulation? http://openmigration.org/ en/analyses/what-is-the-dublin-regulation/

CEASEVAL. M. Wagner, J. Perumadan, and P. Baumgartner. 2019. Research on the Common European Asylum System, Secondary Movements (34). http://ceaseval.eu/ publications/34_SecondaryMovements.pdf

Dublin Regulation. 2008 "Country responsible for asylum application (Dublin)", European Commission. https:// ec.europa.eu/home-affairs/what-we-do/policies/asylum/ examination-of-applicants_en

European Commission v Republic of Poland, Hungary and Czech Republic. Failure of a Member State to fulfil obligations - Decisions (EU) 2015/1523 and (EU) 2015/1601 - Article 5(2) and 5(4) to 5(11).

European Commission. 2019. "Temporary Reintroduction of Border Control". https://ec.europa.eu/home-affairs/ what-we-do/policies/borders-and-visas/schengen/ reintroduction-border-control_en

European Council. 2018. "Council adopts recommendation for continuation of internal border controls". https://www. consilium.europa.eu/en/press/press-releases/2016/05/12/ internal-border-controls/

European Parliament (n.d.) 'Member States' notifications of the temporary reintroduction of border control at internal borders pursuant to Article 25 Jørgensen . of the Schengen Borders Code". https://ec.europa.eu/home-affairs/sites/ homeaffairs/files/what-we-do/policies/borders-andvisas/schengen/reintroduction-border-control/docs/ms_ notifications_-_reintroduction_of_border_control_en.pdf

European Parliament. 2016. "Schengen Borders Code", European Union. http://data.europa.eu/eli/reg/2016/399/oj

"EU Migrant Crisis: Facts and Figures". 2017. European Parliament News. http://www.europarl.europa.eu/ news/en/headlines/society/20170629STO78630/ eu-migrant-crisis-facts-and-figures

European Parliament, Eurostat 2018. "Asylum Statistics - Statistics Explained". Eurostat. http://ec.europa.eu/ eurostat/statistics-explained/index.php/Asylum_statistics

"European Union Terrorism Situation and Trend Report 2018". 2018. European Union Agency for Law Enforcement Cooperation, 3-70. https://doi.org/10.2813/00041

Fanny Hamon and Agathe Fadier. 2018. "Le Droit De l'Union Européenne à l'épreuve Du Paradigme Sécuritaire: Autour Du Refus Du Conseil d'Etat d'annuler La Décision De Maintenir Les Contrôles Aux Frontières: Droit Des Étrangers (Code Frontière Schengen)". Revue Des Droits De l'homme. https://doi.org/10.4000/revdh.3834

Fine, Shoshana. August 2019. "The Integration of Refugees in France", Policy Department for Economic, Scientific and Quality of Life Policies, Directorate-General for Internal Policies, European Parliament, Luxembourg. https://www. europarl.europa.eu/RegData/etudes/STUD/2019/638397/ IPOL_STU(2019)638397(ANNO1)_EN.pdf
Luecke, Matthias and Tim Breemersch. 2016. "Schengen border controls: Challenges and policy options", Policy Department A: Economic and Scientific Policy, European Parliament's IMCO Committee. Brussels.

Maiani, Francesco. 2016. "The reform of the Dublin III Regulations", European Parliament, Policy DepartmentCitizens' rights and constitutional affairs. Brussels. https://www.europarl.europa.eu/RegData/etudes/ STUD/2016/571360/IPOL_STU(2016)571360_EN.pdf

Radjenovic. Anja. 2017. European Parliamentary Research Service, Secondary movements of asylum-seekers in the EU asylum system.

Treaty establishing the European Economic Community and connected documents [1957]. Publishing Services of the European Communities. Luxembourg. https://www.cvce. eu/en/obj/treaty_establishing_the_european_economic community_rome_25_march_1957-en-cca6ba28-0bf34ce6-8a76-6bob3252696e.html

UN General Assembly. 1951. "Convention Relating to the Status of Refugees", United Nations, Treaty Series, vol. 189.

Versteegh, Lia. 2015. "The European Court of Justice and the European Court of Human Rights Determining the State Responsible for Examining an Asylum Application", International Academic Conference Proceedings. https:// hdl.handle.net/11245/1.510632

\section{Border Studies Literature}

Anderson, Malcolm. 1997. Frontiers: Territory and State Formation in the Modern World. Cambridge, UK; Malden, MA: Polity Press.

Diener, Alexander C. and Joshua Hagen. 2012. Borders: A Very Short Introduction. New York: Oxford University Press.

Fondation Robert Schuman. May 18, 2016. "The Schengen area in crisis: the temptation of reinstalling borders", European Issues no 392. https://www.robert-schuman.eu/en/doc/ questions-d-europe/qe-392-en.pdf

Jasiewicz, Jakub. May 16, 2018. "A not-so-temporary reinstatement of internal border controls?" Leiden Law Blog, University of Leiden. https://leidenlawblog.nl/articles/a-not-so-temporary-reinstatement-of-internal-border-controls

Middell, M. 2012. "DeTerritorialization and Reterritorialization", Helmut K. Anheier and Mark Juergenseyer (eds.), Enyclopedia of Global Studies, Thousand Oaks.

\section{Migration Literature}

Koenig, Nicole. October 21, 2016. "France and Germany in the Refugee Crisis: United in Diversity?" Jacques Delors Institute. http://www.institutdelors.eu/wp-content/uploads/2018/01/refugeecrisis-koenig-jdib-oct16. pdf?pdf $=o k$

Nail, Thomas. 2016. "A Tale of Two Crises: Migration and Terrorism after the Paris Attacks: Migration and Terrorism after the Paris Attacks". Studies in Ethnicity and Nationalism 16(1): 158-167. https://doi.org/10.1111/sena.12168

Popkin, Jeremy David. 2020. "France". Encyclopædia Britannica. https://www.britannica.com/place/France

Postelnicescu, Claudia. 2016. "Europe's New Identity: The Refugee Crisis and the Rise of Nationalism", Europe's Journal of Psychology 12(2): 203-209. https://doi. org/10.5964/ejop.v12i2.1191 
Borders in Globalization Review | Volume 1 | Issue 2 | Spring/Summer 2020 Beaupre and Fischer, "The Label 'Refugee' and its Impacts on Border Policies"

Pries, Ludger. 2019. "'We will Manage It'-Did Chancellor Merkel's Dictum Increase or Even Cause the Refugee Movement in 2015?" International Migration. https://doi. org/10.1111/imig.12684

Tebbakh, Sonia. 2007. "Muslims in EU: Cities Report (France)", Open Society Foundation. https:// www.opensocietyfoundations.org/publications/ muslims-eu-cities-background-research-reports

Trines, Stephen. May 2, 2017. “Lessons From Germany's Refugee Crisis: Integration, Costs, and Benefits", World Education News + Reviews.

UNHCR. 2017. "From a Refugee Perspective", Regional Bureau for Europe, Communicating with Communities Unit.44. http://www.unhcr.org/5909af4d4.pdf

UNHCR. 2019. 'UNHCR viewpoint: 'Refugee' or 'migrant'Which is right?" http://www.unhcr.org/news/ latest/2016/7/55dfOe556/unhcr-viewpoint-refugee-migrant-right.html

\section{Discourse Literature}

Abdelkader, Engy. 2017. "A Comparative Analysis of European Islamophobia: France, UK, Germany, Netherlands, and Sweden". Journal of Islamic and Near Eastern Law 16(1): 35-37. https://escholarship.org/uc/item/870099f4

Ahmed, Sarah. 2004. The Cultural Politics of Emotion. Edinburgh: Edinburgh University Press.

Appadurai, Arjun. 1996. Modernity at Large: Cultural Dimensions of Globalization. Minneapolis: University of Minnesota Press.

Baerwaldt, Neske. March 20, 2018. "The European Refugee Crisis: Crisis for Whom?" European Border Communities blog, University of Oxford, Faculty of Law. https://www. law.ox.ac.uk/research-subject-groups/centre-criminology/centreborder-criminologies/blog/2018/03/ european-refugee

Gümplová, Petra. March 10, 2016. "The tragedy of Cologne and its aftermath: the depletion of civility". Open Democracy. https://www.opendemocracy.net/en/can-europe-make-it/tragedy-of-cologne-and-its-aftermath-depletion-of-civility/

Jørgensen, Marianne and Louise Phillips. 2002. Discourse Analysis as Theory and Method. London: Thousand Oaks, Calif: Sage Publications.

Kølvraa, Christoffer. 2012. Imagining Europe as a Global Player: The Ideological Construction of a New European Identity within the EU. Peter Lang AG.

Laclau, Ernesto and Chantal Mouffe. 1985 [2001]. Hegemony and Socialist Strategy: Towards a Radical Democratic Politics. London: Verso.

Laurence, Jonathan and Justin Vaisse. 2012. Integrating Islam: Political and Religious Challenges in Contemporary France. Brookings Institution Press.

Wolfreys, Julian. 2008. Transgression: Identity, Space, Time. Palgrave MacMillan: New York.

Zembylas, Michalinos. 2012. "The Affective (Re)Production of Refugee Representations through Educational Policies and Practices: Reconceptualising the Role of Emotion for Peace Education in a Divided Country". International Review of Education 58(4): 465-480. https://doi. org/10.1007/s11159-012-9296-2

Zetter, Roger. 2007. "More Labels, Fewer Refugees: Remaking the Refugee Label in an Era of Globalization", Journal of Refugee Studies 20(2):172-192. https://doi.org/10.1093/ jrs/fem011 